\title{
Typhoid Vaccine
}

National Cancer Institute

\section{Source}

National Cancer Institute. Typhoid Vaccine. NCI Thesaurus. Code C96392.

A bacterial vaccine used to prevent typhoid fever, which is caused by Salmonella typhi bacteria. 